\title{
AN IMPROVED METHOD FOR THE DETERMINATION OF WATER BALANCE ${ }^{1}$
}

\author{
By F. H. WILEY ${ }^{2}$ and L. H. NEWBURGH \\ (From the Department of Internal Medicine, Medical School, University of Michigan, \\ Ann Arbor)
}

(Received for publication May 22, 1931)

An earlier publication from this laboratory (1) dealt with the measurement of total water exchange. In the interval, the application of this method has given rise to a number of modifications which increase the accuracy of the results obtained, so that it appears advisable to discuss the subject again.

In a recent article (2), we have shown that the method of Benedict and Root (3) for the estimation of basal heat production from the insensible loss of weight, is subject to rather large errors. On the other hand, we have pointed out (4) that the determination of the amount of water vaporized in twenty-four hours gives an accurate method for estimating the total energy exchange in individuals under conditions of normal activity. This paper will deal with the water balance in one of these individuals on two different diets, since this data is well suited for the discussion of the principles involved. A portion of the data of this experiment is being reported in another publication (5).

The estimation of water balance necessitates the direct determination, or the calculation of, four sources of water to the organism, and of three means of excretion of water from it. The factors involved in water balance may be advantageously listed as follows:

Excretory water

1. Water of urine.

2. Water of stool.

3. Insensible water
Sources of water

4. Water of food.

5. Water drunk.

6. Water of oxidation.

7. Preformed water.

1 The expenses of this investigation were defrayed in part by a fund for the study of nutrition created by Mr. W. K. Kellogg, of the Kellogg Corn Flake Company, Battle Creek, Michigan.

${ }^{2}$ National Research Council Fellow in Medicine. 
Let us first consider those factors which can be determined directly.

1. For the determination of the water excreted in the urine, an aliquot of the specimen is placed in a tared weighing bottle, frozen and evaporated in a vacuum desiccator until it reaches constant weight. From the weight of the solids of the aliquot used, the total solids in the entire specimen can be calculated. The difference between the weight of the urine and the weight of the solids contained therein, represents the water thus excreted.

2. The water content of the stool can best be determined by evaporating the entire weighed specimen on a steam bath until its weight is constant, and the weight lost in this process represents the water content of this portion of the excreta. ${ }^{3}$

3. We have found it very convenient to place the subjects on a special diet, which, for short periods of observation, may be repeated each day, or, for longer periods, in order to avoid monotony, may consist of three twenty-four hour diets which are repeated in cycles of three days. In the latter case, the water balance is also determined in three day periods. A sample of the diet is prepared as nearly as possible like that served to the subject, dried and its dry weight determined. The water content of a diet depends considerably upon its preparation, but the dry weight varies only slightly from day to day. Accordingly, this value is subtracted from the total wet weight of the food for any period to determine the water of this portion of the ingesta.

4. The determination of the weight of the water drunk is a simple process. We have found it convenient to use a large thermos bottle fitted with a drinking tube. The bottle may be filled and weighed at the beginning of the period and weighed again at the end of the period. The difference in the weights represents the weight of the water drunk.

5. The determination of the weight of the water lost insensibly from the skin and lungs for any period, has been discussed at length in an earlier publication (4). We have found that the second approximation of the insensible water, obtained by the method described, is sufficiently accurate.

6. The determination of the water of oxidation depends on an accurate knowledge of the composition of the metabolic mixture. After

${ }^{3}$ Such specimens lose an additional small but negligible amount of weight in the vacuum desiccator. 
estimating the heat production from the insensible water, as described previously (4), the calculation of the metabolic mixture follows directly. The amount of protein burned may be calculated by multiplying the excretory nitrogen by 6.25 . In the previous article (4), it was shown that, after a few days on any diet, the carbohydrate of the diet is equal to the carbohydrate of the metabolic mixture. If we now subtract from the total heat production, the heat derived by the oxidation of protein and carbohydrate (i.e. 4 Calories per gram in each case), the difference is the heat derived from the oxidation of fat. This value divided by 9.54 will give the grams of fat oxidized. Thus we now have the three factors making up the metabolic mixture.

The water produced in the oxidation of this mixture is calculated by means of the following constants: Protein yields 0.41 gram of water for each gram oxidized, while 1.07 gram of water is derived from each gram of fat. The water of oxidation of the carbohydrate may be accurately obtained by estimating, from the diet sheet, the amounts of glucose, sucrose and starch making up the total weight of the carbohydrate portion. The water produced by the oxidation of one gram of each of these carbohydrates is as follows: glucose, 0.60 gram; sucrose, 0.58 gram; and starch, 0.556 gram. The sum of the values obtained for protein, fat, and carbohydrates is the total water formed by the oxidation of the food in any period.

(7) The preformed water entering into the consideration of water balance is the amount of water accompanying any storage of tissue, or the amount of water previously held by any body tissue oxidized during the period. Since it is classified with the sources of water, it will be positive when there is a destruction of body tissue, or negative when there is a deposition of new body tissue. If neither of these processes obtains, the preformed water is zero. Protein holds three times its weight of water, and fat holds water to the extent of about 10 per cent of its weight.

The deposition or destruction of body tissue is related to the energy balance. The extent of the storage of potential energy can be obtained, of course, by comparing the total energy available to, and the transformation of energy of the subject over any period. A fairly accurate statement of the available energy may be obtained from the composition of the diet, since protein and carbohydrate have 4 calories 
available for each gram of footstuff, and fat, due to failure in absorption, yields about 9 calories for each gram ingested. When this sum is greater than the transformation of energy, there must be an accompanying storage of tissue, and the preformed water is accordingly negative. If protein is involved, the extent of its destruction or deposition can be obtained by comparing the protein intake with the oxidation of protein as represented by the excretory nitrogen. The energy accompanying this shift in body protein is 4 Calories per gram. The remainder of the energy deposited in, or obtained from the destruction of body tissue, must be due to the change in the amount of body fat, since carbohydrate balance was established prior to the experimental period. This value, divided by 9.54 , gives the magnitude of the shift in the fat content. The weight of the fat and protein deposited or destroyed multiplied by 0.1 and 3.0 respectively, gives the amount of preformed water involved.

We have found that a more accurate knowledge of the metabolic mixture and the preformed water may be obtained by the use of the total heat values of the diet and the excreta. It must be remembered that when protein is oxidized in the bomb calorimeter, it yields 5.65 Calories per gram, and when oxidized in the animal body it yields only 4 Calories per gram due to incomplete oxidation. In the latter case, the unreleased energy is contained in the urine in the form of excretory products of protein metabolism. The oxidation of the average mixed fat in the calorimeter produces 9.54 Calories per gram of material. When the material is burned in the body it also yields 9.54 Calories. But in calculating the energy available from the fat ingested, the value usually used is 9 Calories per gram, to correct for the failure of the organism to completely absorb all of the fat ingested. On the other hand, an average mixture of carbohydrates, since they are completely absorbed and oxidized to carbon dioxide and water in the body, yield their full heat value (i.e. 4 Calories per gram) to the organism. If we now obtain the full heat value of the diet and stool by analyzing them in the bomb calorimeter, and calculate the energy content of the urine by multiplying its nitrogen by 8 , the difference between the energy of the diet and the energy lost in the excreta, is the energy available to the organism. When the available energy is compared with the heat production, the amount of energy stored as tissue or liberated by destruction of tissue, is obtained. 
It is next necessary to determine the weights of protein and fat involved. But this requires a prior knowledge of the composition of the diet. This may be obtained in the following manner: The dietary nitrogen multiplied by 6.25 gives the protein. The dried diet analyzed by the method of Soxhlet gives the fat. The total heat value (bomb calorimeter) of the diet less the energy contained in protein and fat (i.e. protein $\times 5.65$ and fat $\times 9.54$ ) gives the energy content of the carbohydrate portion. This value divided by 4 is the weight of carbohydrate in the diet.

Let us now assume that the available energy was greater than the heat production, and that there was also a nitrogen retention. The nitrogen is presumably stored as protein, and the energy thus laid down is the nitrogen retension $\times 35.3$ (i.e. $6.25 \times 5.65$ ). The total energy stored (available energy - heat production) less the energy stored in the protein gives the energy deposited as fat. The weight of the fat is obtained by dividing this value by 9.54 . The preformed water, in this case, is a negative value, since tissue is deposited.

When energy is stored but body protein is destroyed, the total protein oxidized less dietary protein, gives the amount of body protein destroyed. This protein yields 4 Calories of energy and 3 grams of preformed water per gram of protein. The available energy here is the sum of the total energy of the diet and the total energy of body protein oxidized less the energy contained in the urine and stool. The energy stored is obtained by subtracting the heat production from the available energy. Since this is all stored as fat, the amount of fat deposited can be obtained by dividing this value by 9.54 . The preformed water of the protein is in this case a positive value, and that of the fat is negative. The net preformed water is the algebraic sum of the two.

When the heat production is greater than the available energy, the calculation of preformed water involves the principles described above.

The water balance may now be obtained by supplying the numerical values to the water balance form on page 723 . The total water in, less the excretory water, gives the water balance. If this difference is negative, there has been a loss of water previously held by the body, and if positive, it indicates a retention of water other than that stored with the tissue. 


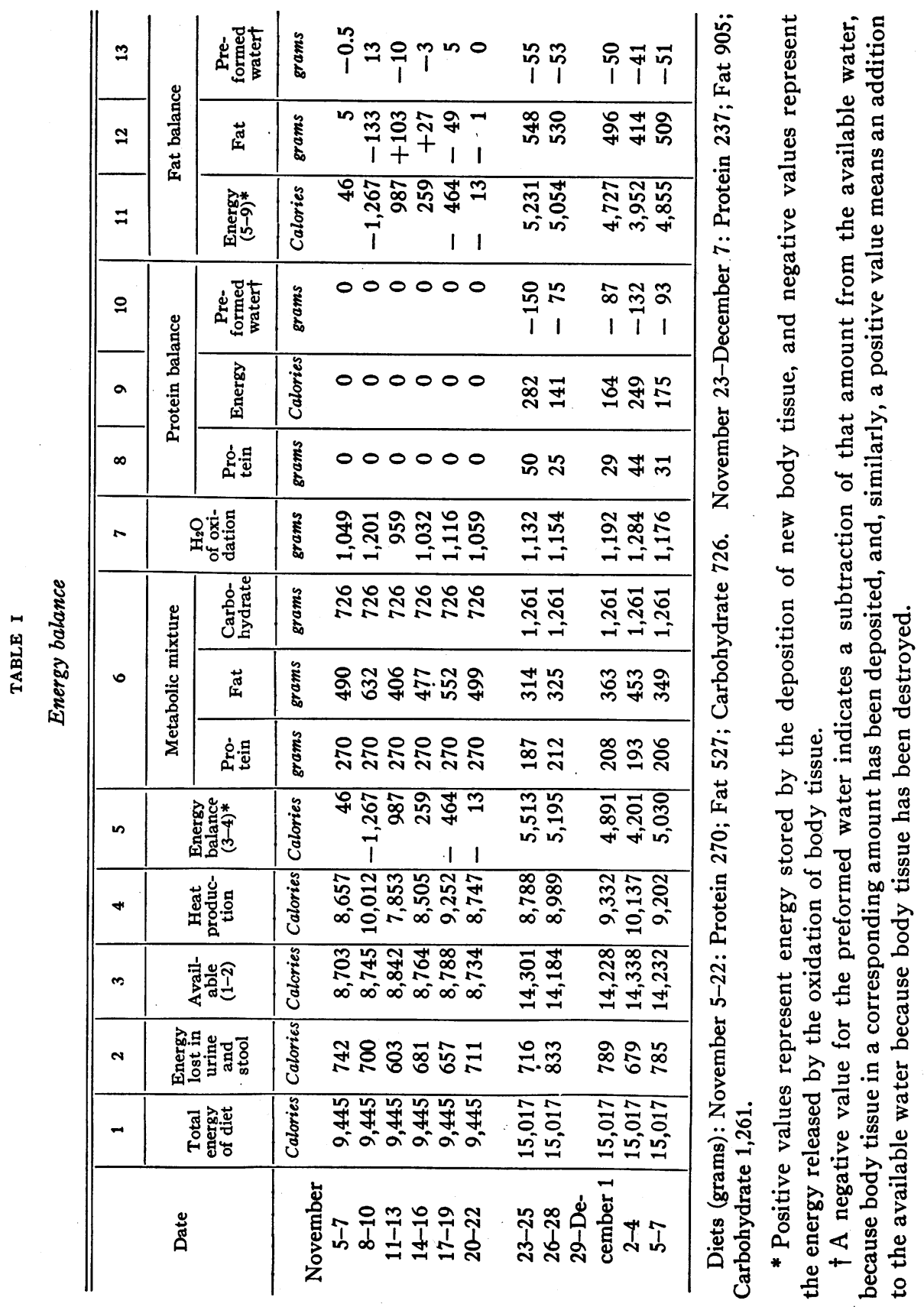


The use of this method may be exemplified by means of the data obtained from a normal subject who first received a maintenance diet and then a supermaintenance diet. These data are presented in Tables I and II. Table I deals with energy balance for the periods. Table II contains a typical water balance sheet for each period.

In Table I the values expressed in columns 1 and 2 were obtained in the bomb calorimeter. The heat production was obtained from the insensible water by the method previously described (4). From November 5 th to the 22 nd the subject was in nitrogen equilibrium and consequently there was no shift in body protein. Hence all of the preformed water accompanied the shift in body fat.

TABLE II

Water balance

\begin{tabular}{|c|c|c|c|c|c|c|c|c|c|}
\hline \multirow[b]{2}{*}{ Date } & 1 & 2 & 3 & 4 & 5 & 6 & 7 & 8 & 9 \\
\hline & $\begin{array}{l}\text { Water } \\
\text { of food } \\
\text { and } \\
\text { water } \\
\text { drunk }\end{array}$ & $\begin{array}{c}\text { Water } \\
\text { of } \\
\text { oxida- } \\
\text { tion }\end{array}$ & $\begin{array}{c}\text { Pre- } \\
\text { formed } \\
\text { water * }\end{array}$ & $\begin{array}{c}\text { Water } \\
\text { in } \\
(1+2 \\
+3)\end{array}$ & $\begin{array}{l}\text { Water } \\
\text { of } \\
\text { urine }\end{array}$ & $\begin{array}{l}\text { Water } \\
\text { of } \\
\text { stool }\end{array}$ & $\begin{array}{l}\text { Insen- } \\
\text { sible } \\
\text { water }\end{array}$ & $\begin{array}{c}\text { Water } \\
\text { out } \\
(5+6 \\
+7)\end{array}$ & $\begin{array}{c}\text { Water } \\
\text { balance } \\
(4-8)\end{array}$ \\
\hline & grams & grams & grams & grams & grams & grams & grams & grams & grams \\
\hline November $5-7$ & 5661 & 1049 & 0 & 6710 & 2673 & 436 & 3582 & 6691 & 19 \\
\hline $8-10$ & 5719 & 1201 & 13 & 6933 & 2354 & 444 & 4144 & 6942 & -9 \\
\hline $11-13$ & 5328 & 959 & -10 & 6277 & 2276 & 364 & 3250 & 5890 & 387 \\
\hline $14-16$ & 5900 & 1032 & -3 & 6929 & 3123 & 393 & 3519 & 7035 & -106 \\
\hline $17-19$ & 5394 & 1116 & +5 & 6515 & 1948 & 446 & 3828 & 6222 & 293 \\
\hline \multirow[t]{2}{*}{$20-22$} & \multirow[t]{2}{*}{5891} & \multirow[t]{2}{*}{1059} & \multirow[t]{2}{*}{0} & \multirow[t]{2}{*}{6950} & \multirow[t]{2}{*}{3446} & \multirow[t]{2}{*}{447} & \multirow[t]{2}{*}{3619} & 7512 & -562 \\
\hline & & & & & & & & Total & 22 \\
\hline $23-25$ & 5858 & 1132 & -205 & 6785 & 1588 & 447 & 3636 & 5671 & 1114 \\
\hline $26-28$ & 5752 & 1154 & -128 & 6728 & 2689 & 518 & 3719 & 6926 & -178 \\
\hline \multicolumn{10}{|l|}{ November 29- } \\
\hline December 1 & 5525 & 1192 & -137 & 6580 & 2591 & 350 & 3863 & 6804 & -224 \\
\hline $2-4$ & 5826 & 1284 & -173 & 6937 & 2200 & 318 & 4194 & 6712 & 225 \\
\hline \multirow[t]{2}{*}{$5-7$} & \multirow[t]{2}{*}{4925} & \multirow[t]{2}{*}{1176} & \multirow[t]{2}{*}{-144} & \multirow[t]{2}{*}{5957} & \multirow[t]{2}{*}{1750} & \multirow[t]{2}{*}{420} & \multirow[t]{2}{*}{3807} & 5977 & -20 \\
\hline & & & & & & & & Total & 897 \\
\hline
\end{tabular}

* A negative value represents water held with stored tissue.

During the first six days ( 2 periods) on the supermaintenance diet the subject added 936 grams of water to his body (November 23-28, Table II). He also stored glycogen with its preformed water. It is 
impossible to determine how much glycogen was added, and consequently there is no way of knowing what portion of this 936 grams of new water was laid down as a normal constituent with the glycogen. This is an example of the way in which the method fails to give the desired information about water exchange when the body store of glycogen is changing. However, the subject could not have added more than 200 grams of glycogen, and this amount would require at most 600 grams of water, leaving 336 grams to be accounted for. This reasoning brings out the point that the subject during these six days has added water to his body in two different ways, since, after subtracting the maximum that can be included under the head of preformed water, there remains several hundred grams held in the body for some unknown reason. This latter increment seems to be a lasting addition since it did not come out in the next nine days. This might simply have been the amount of water held with the extra food in the gastrointestinal tract.

If we return now to the water balance obtained while the subject was on a maintenance diet (November 5-22, Table II), it will be seen that there was a noteworthy variation in the water content of the body from period to period in spite of the constancy of the diet. This shift cannot be attributed to changes in activity, as may be seen by comparing heat production and water balance. It emphasizes the lability of the mechanism which regulates the water content of the normal individual. For purposes of study it permits one to regard edema and its counterpart, dehydration, as disturbances of this mechanism brought about either by naturally occurring disease or by conditions set up by the investigator.

A common clinical method of studying the water exchange depends solely upon a comparison of the water drunk and the urine output. The values set forth in Table II show how erroneous such a consideration is. For instance, throughout the experiment the insensible loss of water through the skin and lungs was greater than the total water lost in the urine. The water of oxidation varied from 30 per cent to 75 per cent of the water eliminated in the urine. The average water drunk per period of three days was 3600 grams, and the average water in the urine was 2400 grams. A consideration of these two values alone would indicate a water retention of about 1200 grams per period, or a total 
retention of 13 kilograms of water during the entire experiment. As is shown in Table II, the actual retention for the entire experiment was less than 1 kilogram. It is evident then that none of the factors involved in the water exchange can be omitted if an accurate knowledge of the water balance is to be obtained.

\section{BIBLIOGRAPHY}

1. Newburgh, L. H., Johnston, M. W., and Falcon-Lesses, Mark, J. Clin. Invest., 1930, viii, 161: Measurement of Total Water Exchange.

2. Wiley, F. H., and Newburgh, L. H., J. Clin. Invest., 1931, x, 689. The Relationship Between the Environment and the Basal Insensible Loss of Weight.

3. Benedict, F. G., and Root, H. E., Arch. Int. Med., 1926, xxxviii, 1. Insensible Perspiration; Its Relation to Human Physiology and Pathology.

4. Newburgh, L. H., Wiley, F. H., and Lashmet, F. H., J. Clin. Invest., 1931, x, 703. A Method for the Determination of Heat Production Over Long Periods of Time.

5. Wiley, F. H., and Newburgh, L. H., J. Clin. Invest., 1931, x, 733. The Doubtful Nature of "Luxuskonsumption." 